\title{
AC 2007-37: RETENTION OF STEM STUDENTS WITH THE EMC^2 SCHOLARS' PROGRAM AT RIT
}

\section{Surendra Gupta, Rochester Institute of Technology}

"Vinnie" Gupta is a Professor of Mechanical Engineering and Materials Science \& Engineering, and the recipient of the 2000 Eisenhart Award for Excellence in Teaching. At RIT, he teaches undergraduate and graduate courses in Applied Mechanics, Computational Techniques, and Materials Science.

\section{Edward Hensel, Rochester Institute of Technology}

Ed Hensel is a Professor and the Head of the Department of Mechanical Engineering. He teaches courses involving multi-disciplinary design.

\section{Andreas Savakis, Rochester Institute of Technology}

Andreas Savakis is a Professor and the Head of the Department of Computer Engineering. He teaches courses in Digital Image Processing, Digital Control Systems and Introduction to Computer Engineering.

\section{Paul Tymann, Rochester Institute of Technology}

Paul Tymann is an Associate Professor of Computer Science. His teaching and research interests are in Computer architecture, operating systems, networking, parallel computing, object oriented programming and design.

\section{Darren Narayan, Rochester Institute of Technology}

Darren Narayan is an Assistant Professor and the Director of Undergraduate Research in Mathematics. He received a BS in Mathematics from SUNY Binghamton in 1994 and attended Lehigh University for his graduate work receiving an MS in 1998 and Ph.D. in 2000. 


\title{
Retention of STEM Students with the EMC ${ }^{2}$ Scholars' Program at RIT
}

\begin{abstract}
This paper details our highly successful scholarship and academic support program to retain and graduate students in four academic departments: Mechanical Engineering, Mathematics, Computer Engineering, and Computer Science $\left(\mathrm{EMC}^{2}\right)$. The EMC ${ }^{2}$ Scholars' program is supported by a 4-year grant from the National Science Foundation's CSEMS (Computer Science, Engineering and Mathematics Scholarships) program and matching funds from the Rochester Institute of Technology (RIT). The project, to expire in August 2006, was recently granted a oneyear no-cost extension. The paper describes the processes for selection of scholars and renewal of scholarship, and includes data on department distribution, student demographics and retention. It describes programmatic elements that worked or did not work in retaining students in CSEMS degree programs. The program's retention rates exceed RIT's averages - at each year level and within each of the four academic programs. The program has been successful in developing a partnership among the four academic departments, and has strengthened the coordination mechanisms with the supporting units. Successful EMC ${ }^{2}$ elements are being deployed elsewhere at RIT to retain female and minority students.
\end{abstract}

\section{Introduction}

In Fall 2002-3, the National Science Foundation (NSF) awarded a 4-year grant of $\$ 392,000$ from its 2002 CSEMS program ${ }^{1,2}$. Rochester Institute of Technology (RIT) is providing $\$ 526,500$ in matching funds to support the scholarships. The EMC ${ }^{2}$ Scholars Program is a collaborative effort of four academic programs: Mechanical Engineering, Mathematics, Computer Engineering, and Computer Science. The goal of this scholarship program is to retain and graduate academically talented students in the four participating units. The scholars receive $\$ 1,000$ per quarter until they complete their first co-op experience. The pre-co-op support does not exceed seven quarters. NSF and RIT are each contributing \$500 per quarter per scholar. After their first co-op experience, the scholars retain the $\$ 500$ per quarter scholarship from RIT until they graduate at the end of 12 academic quarters. The project, which was to expire in August 2006, was recently granted a one-year no-cost extension by NSF.

We have been successful in developing a partnership among the four academic departments, and strengthening the coordination mechanisms with supporting units that include the Undergraduate Admissions, Financial Aid, Registrar's Office, Academic Support Center, and Career Services ${ }^{3,4}$. This paper describes the relationships and mechanisms we have developed with these supporting units to administer the $\mathrm{EMC}^{2}$ program.

\section{Selection of Scholars and Scholarship Renewal}

Each Spring/Summer, the Senior Associate Director of Financial Aid identifies all eligible $1^{\text {st }}$ year applicants offered admission to RIT, and selects $\sim 33$ (50\% more than scholarships available) for $\mathrm{EMC}^{2}$ scholarships based on financial need and academic potential. From this 
group, approximately $211^{\text {st }}$ year students choose RIT and accept the EMC ${ }^{2}$ scholarship. She also provides the Program Administrator a list of all eligible $2^{\text {nd }}$ and $3^{\text {rd }}$ students sorted by financial need and cumulative GPA. Together, they select appropriate number of students for a total of 62 EMC $^{2}$ scholarship awards. Since 2006-7 is the last year of the grant, no new awards have been made.

Of the $62 \mathrm{EMC}^{2}$ scholars supported each year with $\$ 1,000 /$ quarter scholarships, approximately $50 \%$ are matriculated in mechanical engineering, $30 \%$ in computer engineering, $15 \%$ in computer science, and $5 \%$ in the mathematics program. If a scholar transfers out of the four participating academic departments, his/her scholarship is not renewed in the following academic year. If a scholar's quarterly GPA falls below 2.50 for two sequential quarters, again the scholarship is not renewed in the following academic year. In either case, a new scholarship recipient is selected at the same year-level within the same department based on financial need and academic performance. Table I summarizes the departmental distribution for each of the academic years (AY):

\section{TABLE I}

DISTRIBUTION OF SCHOLARS

\begin{tabular}{|c|c|c|c|c|c|}
\hline $\begin{array}{c}\text { Academic } \\
\text { Year } \\
\text { (AY) }\end{array}$ & $\begin{array}{c}\text { Mechanical } \\
\text { Engineering }\end{array}$ & $\begin{array}{c}\text { Computer } \\
\text { Engineering }\end{array}$ & $\begin{array}{c}\text { Computer } \\
\text { Science }\end{array}$ & Mathematics & Total \\
\\
\cline { 2 - 5 } $2002-3$ & 31 & 19 & 9 & 3 & 62 \\
\hline $2003-4$ & 46 & 28 & 13 & 4 & 91 \\
\hline $2004-5$ & 62 & 39 & 16 & 8 & 125 \\
\hline $2005-6$ & 74 & 45 & 15 & 5 & 139 \\
\hline $2006-7$ & 53 & 32 & 10 & 2 & 97 \\
\hline
\end{tabular}

The data in the table above shows clearly that the EMC ${ }^{2}$ program approximately maintained its 50-30-15-5 departmental distribution target in the first four years of the project. Please note that the figures above include 62 scholars receiving $\$ 1000$ /quarter as well as scholars receiving $\$ 500 /$ quarter only during the post co-op period.

\section{Student Demographics and Retention}

In selecting students for scholarship awards, for comparable financial need and academic performance, preference is given to female and minority students (under-represented groups such as African Americans, Native Americans and Latin Americans) ${ }^{5}$. Table II below summarizes the student demographics: 
TABLE II

DEMOGRAPHIC DISTRIBUTION OF SCHOLARS

\begin{tabular}{|c|c|c|c|c|c|c|c|c|c|}
\hline $\begin{array}{c}\text { Academic } \\
\text { Year }\end{array}$ & Total & $\#$ & \multicolumn{2}{|c|}{ Gender } & \multicolumn{6}{|c|}{ Ethnicity* } \\
\cline { 3 - 10 } & Male & Female & WC & AA & LA & NA & AP & UR \\
\hline $2002-3$ & 62 & 43 & 19 & 39 & 7 & 7 & 0 & 6 & 3 \\
\hline $2003-4$ & 91 & 76 & 15 & 69 & 8 & 3 & 2 & 6 & 3 \\
\hline $2004-5$ & 125 & 103 & 22 & 86 & 10 & 13 & 3 & 10 & 3 \\
\hline $2005-6$ & 139 & 113 & 26 & 101 & 12 & 13 & 2 & 9 & 2 \\
\hline $2006-7$ & 97 & 78 & 19 & 71 & 7 & 7 & 2 & 8 & 2 \\
\hline
\end{tabular}

*Ethnicity Key

$\mathrm{WC}=$ Caucasian; $\mathrm{AA}=$ African American $; \mathrm{LA}=$ Latin American; NA = Native American; $\mathrm{AP}=$ Asian American or Pacific Islander; UR = Not Reported

The data in the table above shows that the proportion of female students among the EMC ${ }^{2}$ scholars is significantly higher than that within the four participating departments. Similarly, the proportion of African Americans, Latin Americans and Native Americans (AALANA population) among the $\mathrm{EMC}^{2}$ scholars is also significantly higher than that within the four participating departments.

Each quarter, the Registrar's Office provides the Program Administrator a customized report containing personal and academic information on each $\mathrm{EMC}^{2}$ scholar. The report helps in identifying students that

1. need academic intervention,

2. have left the participating academic programs, or

3. are on Deans' Lists for superior academic performance.

The report is also useful in quarterly updates of NSF-CSEMS database and preparation of the annual report to NSF as required by the conditions of the grant.

Students needing academic intervention are asked to meet with their departmental EMC $^{2}$ faculty advisor to identify and enroll in an appropriate program of the Academic Support Center. Students that have transferred out of the $\mathrm{EMC}^{2}$ programs are sent an email informing them of the discontinuance of scholarship at the end of the academic year. Students on the Deans' Lists are sent a congratulatory email in addition to normal recognitions.

At the end of each academic year, the EMC ${ }^{2}$ program's retention figures exceed the institution's averages - at each year level and within each program. In table III below, $\mathrm{EMC}^{2}$ represents scholars retained in the four participating departments, CSEMS represents scholars who transferred to other CSEMS disciplines at RIT, Other represents scholars who transferred to nonCSEMS disciplines at RIT, and Left shows scholars who left RIT. 
TABLE III

\begin{tabular}{|c|c|c|c|c|c|c|}
\multicolumn{2}{c|}{ RETENTION AND GRADUATION DATA ON EMC ${ }^{2}$ SCHOLARS } \\
\hline AY & Total & $\begin{array}{c}\text { EMC } \\
\text { Programs } \\
\text { at RIT }\end{array}$ & $\begin{array}{c}\text { CSEMS } \\
\text { Programs } \\
\text { at RIT }\end{array}$ & $\begin{array}{c}\text { Other } \\
\text { Programs } \\
\text { at RIT }\end{array}$ & $\begin{array}{c}\text { Left } \\
\text { RIT }\end{array}$ & $\begin{array}{c}\text { Gradu- } \\
\text { ated }\end{array}$ \\
\hline $2002-3$ & 62 & 48 & 6 & 5 & 3 & NA \\
\hline $2003-4$ & 91 & 89 & 1 & 1 & 0 & NA \\
\hline $2004-5$ & 125 & 124 & 0 & 0 & 1 & 9 \\
\hline $2005-6$ & 139 & 125 & 11 & 1 & 2 & 27 \\
\hline $2006-7$ & 97 & 97 & & & & \\
\hline
\end{tabular}

The data above shows clearly that the EMC ${ }^{2}$ program has been very successful in retaining students within the CSEMS disciplines (including the $\mathrm{EMC}^{2}$ disciplines) at RIT.

\section{Program Elements and Their Assessment}

In Spring 2002-3, $1^{\text {st }}$ year scholars met bi-weekly in groups of five with a faculty moderator to improve their learning skills and study strategies ${ }^{6}$. The program was designed by the Director of Learning Development Center (now known as the Academic Support Center). These scholars were simultaneously enrolled in the institute-wide non-credit First Year Experience (FYE) course as well as the mandatory departmental Freshman Seminar course. The scholars reported that there was much overlap in the three activities. Based on the feedback from the scholars, in subsequent years these activities were streamlined and better integrated in the two-quarter Freshmen Seminar course now taken by all incoming $1^{\text {st }}$ year students. During AY2004-05, the FYE course and departmental freshman seminars were integrated as part of an institute-wide pilot program. In AY2005-6, the lessons learned were incorporated across the entire campus and the FYE course was assigned one academic credit.

Early each Fall quarter, all EMC ${ }^{2}$ scholars, participating staff and faculty are invited to a reception and dinner at the RIT Inn. The Program Administrator makes welcoming remarks followed by an elegant sit-down dinner. During desserts and coffee, participants are asked to introduce themselves. The event provides an opportunity to collect information from each scholar that is required by NSF to update their CSEMS database. This Fall, scholars were asked to provide feedback and concrete suggestions to enhance their experience at RIT. An overwhelming majority of issues were non-academic. Many of the suggestions and concerns have been echoed in other student surveys at RIT, and are being addressed by the RIT administration. EMC ${ }^{2}$ faculty assessed the dinners to be a highly successful event promoting camaraderie and pride.

Each quarter, the Program Administrator reviews the academic performance of each scholar. If a scholar's quarterly GPA falls below 2.50 , he/she is asked to meet with the departmental EMC ${ }^{2}$ faculty advisor to identify and enroll in an appropriate academic support program7. RIT has an excellent support infrastructure to meet students' academic and non-academic needs. The retention data in the previous section shows that this quarterly review process has been effective. 
Last three Spring quarters, we wanted to hold a year-end get-together. However, we were unable to find an appropriate evening during the last four weeks of the quarter because of conflicts with already scheduled major institute or college events. The Spring get-together would have been an excellent opportunity to collect formal feedback from the scholars about the EMC ${ }^{2}$ program elements.

Encouraged by the success of $\mathrm{EMC}^{2}$ program, a group of faculty in engineering and engineering technology wrote another proposal to NSF two years ago and were successful in obtaining another 4-year grant ${ }^{7}$. They hope to recruit additional transfer students from 2-year colleges, retain and graduate them ${ }^{8}$. They are using many of the elements of the EMC ${ }^{2}$ program ${ }^{9}$.

\section{Acknowledgment}

Financial support from the National Science Foundation through grant \# DUE-0220782 is gratefully acknowledged.

\section{References}

[1] Vedula, K., "Opportunities for Engineering Education Funding at the National Science Foundation", Proceedings of the 2004 ASEE Annual Conference, 2004.

[2] Seals, R. K., "National Science Foundation - Opportunities and Resources, Programs of the Division of Undergraduate Education", Proceedings of the 2004 ASEE Annual Conference, 2004.

[3] Komerath, N. M. and Smith, M. J., "Mentoring Students to Technology Careers", Proceedings of the 2004 ASEE Annual Conference, 2004.

[4] Kukulka, D. J., Barker, D. S., Favata, J. and Sanders, R., "Implementation of the Computer Science, Engineering Technology, and Mathematics Scholarship (CSEMS) Program at Buffalo State College", Proceedings of the 2004 ASEE Annual Conference, 2004.

[5] Moskal, B. M., Lasich, D. and Middleton, N., "Science Related Degrees: Improving the Retention of Women and Minorities through Research Experience, Mentoring and Financial Assistance", Proceedings of the 2001 ASEE Annual Conference, 2001.

[6] Bayles, T. M., Spence, A. M. and Morrell, C., "Improving the Freshman Engineering Experience", Proceedings of the 2004 ASEE Annual Conference, 2004.

[7] Richardson, C. A., Gupta, S. K., Valentine, M. L., Merrill, R. and Amuso, V. J., "Multi-department Engineering and Engineering Technology Transfer Scholars Program", Proceedings of the 2005 ASEE Annual Conference, 2005.

[8] Dimitriu, D. G. and O’Connor, J., "Forging Stronger Ties between Community Colleges and Four Year Universities", Proceedings of the 2004 ASEE Annual Conference, 2004.

[9] Gupta, S. K., Hensel, E. C., Savakis, A., Tymann, P. and Narayan, D., "Retaining Female and Minority Students with EMC ${ }^{2}$ Scholars Program”, Proceedings of the 2005 ASEE Annual Conference, 2005. 